\title{
Seasonal Habitat Use and Movements of Mountain Goats, Oreamnos americanus, in East-central British Columbia
}

\author{
KIM G. Poole ${ }^{1}$ and Douglas C. HeARD ${ }^{2}$ \\ ${ }^{1}$ Aurora Wildlife Research, 2305 Annable Rd., Nelson, British Columbia V1L 6K4 Canada; e-mail: klpoole@shaw.ca \\ ${ }^{2}$ British Columbia Ministry of Water, Land and Air Protection, $405118^{\text {th }}$ Avenue, Prince George, British Columbia V2N 1B3 \\ Canada; e-mail: doug.heard@gems7.gov.bc.ca
}

Poole, Kim G., and Douglas C. Heard. 2003. Seasonal habitat use and movements of Mountain Goats, Oreamnos americanus, in east-central British Columbia. Canadian Field-Naturalist 117(4): 565-576.

To identify the potential for adverse effects of forest development on Mountain Goats (Oreamnos americanus), we documented the patterns of forest use by goats and the factors influencing goat habitat use. We used a combination of 15 very high frequency (VHF) and six global positioning system (GPS) radiocollars to document the distribution and movements of 21 (15 female, 6 male) goats from 1997 to 1999 in the mountains surrounding the Robson Valley in east-central British Columbia. Because canopy closure reduces the likelihood that a GPS receiver will obtain a location fix, we estimated that GPS collars underrepresented forest use by about $23 \%$. Three goats used separate winter and summer ranges separated by $8-13 \mathrm{~km}$, while most simply exhibited seasonal shifts in elevation. In winter, goats were more often at lower elevations, in commercial forest stands, on southerly aspects, and moved less each hour and over the course of the winter. Goat use declined in areas $>500 \mathrm{~m}$ from escape terrain and goats were found lower in elevation from evening to dawn compared to daylight hours. Collared goats used high elevation licks, which were either within their home range, or in two cases, 6 and $14 \mathrm{~km}$ from their typical home range. We documented use of known mid-elevation mineral licks by three collared goats, but no use of known low elevation (valley bottom and lower slopes) mineral licks. Robson Valley goats appeared to be at relatively low risk from disturbances related to logging, because although forest use was documented during winter, it occurred primarily on high elevation, steep slopes where trees are currently of low commercial value, and goats made little use of low elevation mineral licks. We recommend that in this area a forested buffer of $500 \mathrm{~m}$ around cliffs be left to reduce the possibility of adverse effects on goats especially, on southerly aspects above $1300 \mathrm{~m}$.

Key Words: Mountain Goats, Oreamnos americanus, British Columbia, distribution, habitat use, home range, mineral licks, movements.

Although often residents of steep alpine terrain, Mountain Goats (Oreamnos americanus; hereafter, goats) use montane forests for food and cover during fall (Demarchi et al. 2000) and winter (Hebert and Turnbull 1977; McCrory et al. 1977; Adams and Bailey 1983; Fox and Smith 1988; Gilbert and Raedeke 1992), when moving to low elevation mineral licks in spring and summer (Hebert and Cowan 1971; Singer and Doherty 1985; Hopkins et al. 1992), and occasionally when moving among high elevation ranges. Environmental changes resulting from forestry operations may, therefore, affect goats, but are still poorly understood (Côté and Festa-Bianchet 2003). Forestry development can increase access and the loss and fragmentation of habitat. Because goats rarely venture far from cliffs that are steep enough to provide a refuge from terrestrial predators (Smith 1986; Haynes 1992), forestry development plans must also consider those terrain features.

In the mountains surrounding the Robson Valley in east-central British Columbia, Canada, forestry activities are encroaching on goat range, pushing farther into previously-undisturbed side valleys of the Fraser River and Kinbasket Reservoir and higher up hillsides toward the alpine zone (Slocan Forest Products Ltd., Valemount Division, Five-year Harvest Plan, April 1997; C. Ritchie, British Columbia Ministry of Environment, Lands and Parks [MELP], Prince George, per- sonal communication). To identify the potential for adverse effects of logging on goat populations, we examined the patterns of movements and forest use by goats with the expectation that forest use by goats would primarily be during the period when they used low elevation mineral licks. Little is known about seasonal movements of goats (Côté and Festa-Bianchet 2003), information which could affect their association with forestry operations. We used a combination of very high frequency (VHF) and global positioning system (GPS) radiocollars to document the distribution and movements of goats. The long battery life and relatively low cost of conventional VHF radiocollars allowed us to monitor 15 goats one to four times each month over two years (1997-1999), providing general movement information throughout the year. The high relocation frequency of GPS collars, during both day and night (Poole and Heard 1998), allowed us to determine the detailed movements of six goats but for a shorter duration.

\section{Study Area}

Our study area encompassed the mountains surrounding approximately 190 linear $\mathrm{km}$ of the Robson Valley in east-central British Columbia (centred on $52^{\circ} 49^{\prime}$ N, $119^{\circ} 15^{\prime}$ W; Figure 1). The Rocky Mountains run along the northeast side of the valley, with 
the Columbia Mountains to the southwest. Goats were monitored up to $28 \mathrm{~km}$ from the main valley. Elevations ranged from $715 \mathrm{~m}$ at the northwest end of the valley bottom to surrounding peaks that were generally between 2600 and $3250 \mathrm{~m}$. Shackleton (1999) rated the relative density of goats in the area as moderate. Within a $2700-\mathrm{km}^{2}$ census zone (above $1675 \mathrm{~m}$ ) encompassing the study animals, the goat density was estimated at 0.8 goats $/ \mathrm{km}^{2}$ (Poole et al. 2000).

Climate varied with elevation, with a general increase in precipitation and decline in temperature with increasing elevation. Mean July and January temperatures for Valemount, located at $797 \mathrm{~m}$ in the centre of the study area, were 15.8 and $-11.0^{\circ} \mathrm{C}$, respectively, with an average annual precipitation of $503 \mathrm{~mm}, 180 \mathrm{~mm}$ of which fall as snow (Environment Canada climate normals, unpublished data). At elevations the goats frequented, snow cover was usually present from about late September to early June. Snow water equivalent data (snow pillow; BC MELP, unpublished data) from monitoring stations at the north (at $1690 \mathrm{~m}$ elevation) and south $(1980 \mathrm{~m})$ ends of the study area indicated that snow depths during winter 1997-1998 were approximately $20 \%$ below normal, while in 1998-1999 they were $5-25 \%$ greater than normal (both stations $n=$ $13 \mathrm{yr}$ ). Spring snow melt in 1998 was about three weeks earlier than normal, while in 1999 it was two to four weeks later than normal.

Four biogeoclimatic zones were represented in the study area, ranging from the sub-boreal spruce (SBS) and interior cedar-hemlock (ICH) zones in the valley bottom, through the Engelmann Spruce-Subalpine Fir (ESSF) zone to the alpine tundra (AT) at the highest elevations (Meidinger and Pojar 1991). Treeline was generally between 1900 and $2150 \mathrm{~m}$. In the valley bottom, hybrid spruce (Picea glauca $\times$ engelmannii), Subalpine Fir (Abies lasiocarpa), Western Hemlock (Tsuga heterophylla), and Western Redcedar (Thuja plicata) were the dominant trees, with extensive stands of Lodgepole Pine (Pinus contorta) due to frequent fires (MacKinnon et al. 1992). Higher up the mountainsides spruce, Subalpine Fir and Lodgepole Pine predominated, with scattered stands of Whitebark Pine (Pinus albicaulis) at the highest elevations. In the AT zone, conifers were present only in stunted krummholz forms in the lower levels of this zone; much of the zone consists of sparse vegetation, rock, talus, and glaciers or semi-permanent snowfields. Cliff formations vary from sheer faces to broken bluffs.

Potential predators of goats (Côté and Festa-Bianchet 2003) within the study area included Wolves (Canis lupus), Grizzly Bears (Ursus arctos), Black Bears (U. americanus), Cougars (Puma concolor), Wolverines (Gulo gulo), and Golden Eagles (Aquila chrysaetos). The main form of industrial development off the Robson Valley was forestry, and most major and some minor watersheds had logging roads along at least part of the valley bottom. Logging was generally at lower elevations and varied greatly in extent among drainages. Most upper elevations and the back ends of most watersheds were undeveloped wilderness. Goat hunting was permitted throughout the study area through open seasons or limited entry quota, depending upon the area (15 August - 15 October), but was generally very light $(\leq 1 \%$ of the population estimate; Poole et al. 2000). Hunters were allowed to shoot one goat/yr of either sex, but were requested to shoot a male.

\section{Methods}

\section{Capture and Telemetry}

We captured goats with a hand-held net gun fired from a Hughes 500, A-star or Bell 206B helicopter wherever we could find goats in suitable terrain (minimizing risk to the animal), while attempting to distribute the radiocollars throughout the study area and ensure some collars were near drainages where forestry development was imminent. Each animal was hobbled, blindfolded, and fitted with horn guards prior to processing. We aged captured goats by counting the number of distinct horn annuli plus the fainter kid annulus formed at six months of age (Smith 1988; Stevens and Houston 1989). We released captured goats generally within 20 minutes of netting. Goat capture protocols were approved by $\mathrm{H}$. Schwantje, the British Columbia Ministry of Environment, Lands and Parks veterinarian, Victoria, who participated in 10 captures.

VHF radiocollars (model LMRT-3, Lotek Engineering Inc., Newmarket, Ontario) weighed $400 \mathrm{~g}$ and were designed to last 35 months. GPS radiocollars (Advanced Telemetry Systems [ATS], Isanta, Minnesota, USA) weighed approximately $950 \mathrm{~g}$ and were equipped with a VHF transmitter and a 12-channel Garmin GPS board (Olathe, Kansas, USA). The GPS collars logged non-differentially correctable horizontal position data in the WGS84 datum, altitude, date, time, satellite identifier, location mode (2- or 3-dimensional [2D or $3 \mathrm{D}]$ ), dilution of precision (DOP), and the time required to obtain a location. The GPS collars operated in auto $2 \mathrm{D} / 3 \mathrm{D}$ mode, meaning that when signals from $\geq 4$ satellites were obtained, a 3D location (horizontal position and elevation) was taken, but if only three satellite signals were obtained, a 2D location (horizontal position only) was taken using the elevation obtained from the last 3D location (Rempel et al. 1995). GPS collars were programmed to obtain a GPS location every six hours on the hour (120-second maximum on time with no retry on failed attempts) and had an estimated 181-day GPS battery life (C. Kochanny, Advanced Telemetry Systems, personal communication). One collar collected locations at 0000, 0600, 1200 and 1800 hours, two collars at 0200, 0800, 1400 and 2000 hours, and three collars at 0300, 0900, 1500 and 2100 hours. GPS collars were released from the animals by a remotely fired mechanism (Mech and Gese 1992), collars were picked up, and data from the collar's memory were downloaded through a direct cable connection to a personal computer. 


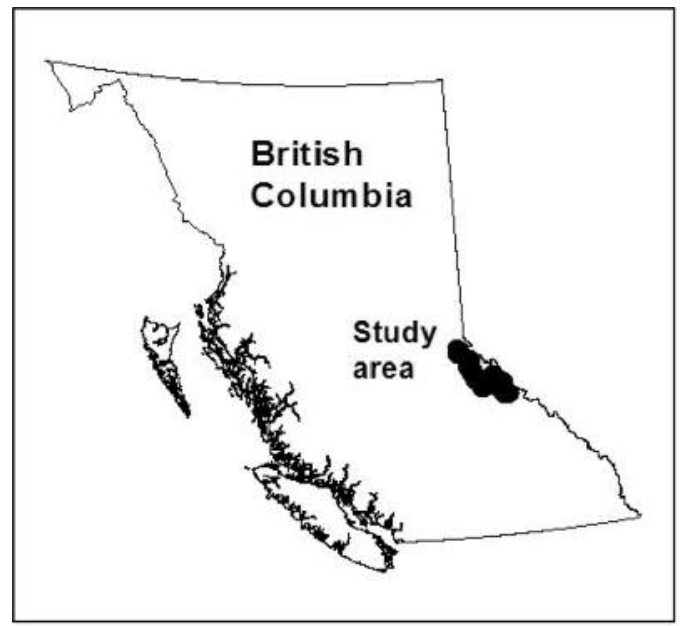

FIGURE 1. Location of the Robson Valley Mountain Goat study, 1997-1999.

We located collared goats using traditional aerial telemetry procedures (Mech 1983; White and Garrott 1990) one to four times monthly using a Cessna 337 with two strut-mounted "H" antennae. Generally, all collared goats were located each flight, although on nine flights poor weather conditions or time restrictions prevented access to every animal. The difficulty of ground access into the study area required that all radiotelemetry monitoring be conducted aerially during daylight hours and good flying weather. During spring and early summer 1998, we often located all goats late in the evening and again early the following morning, to reduce ferry costs per goat location and to maximize the likelihood of locating goats at mineral licks (Singer and Doherty 1985). All other VHF goat locations were $\geq 4$ days apart. At each location we recorded the goat's position using the aircraft's GPS, the vegetation cover and general landscape features and, where possible, group size and composition. All VHF and GPS locations were standardized to Pacific Standard Time.

Accuracy of VHF locations was not tested; however, collared goats were observed on $41 \%$ of the 747 locations. Accuracy of GPS locations was also not tested however, non-differentially corrected locations taken before the Selective Availability feature in the US military GPS was removed on 1 May 2000 are expected to be within $100 \mathrm{~m}$ of the true location, $95 \%$ of the time (Lotek Engineering 1998*). Bowman et al. (2000) found that $84 \%$ of GPS locations for ATS collars on White-tailed Deer (Odocoileus virginianus) were within $100 \mathrm{~m}$ of the actual locations.

To assess the reliability of the location data from the GPS collars, we considered both the accuracy of the individual locations and the potential for bias in the sample of locations. Location accuracy is inversely related to dilution of precision values, and $3 \mathrm{D}$ locations have a higher probability of being more accurate than 2D locations (Trimble Navigation Ltd 1994*; British Columbia Ministry of Environment, Lands and Parks 1995*; Johnson 2000). Whenever GPS location success is $<100 \%$, then GPS locations likely represent a biased sample of habitat use because location success is affected by factors like tree density, canopy cover and topography (Rempel et al. 1995; Moen et al. 1996; Dussault et al. 1999; D’Eon et al. 2002). This was especially important in our study because we were interested in documenting forest use by goats. To assess this bias we considered both the GPS location success rate and the proportion of 2D fixes among seasons. If tree cover reduced the likelihood of obtaining a location, then 2D forest locations should be relatively more common than $3 \mathrm{D}$ forest locations, because the collar must 'see' at least one more satellite for a 3D location.

\section{Spatial Analysis}

We imported goat locations into a geographic information system (GIS; ARC/INFO; Environmental Systems Research Institute, Redlands, California, USA) for mapping and spatial analysis, and determination of vegetation cover and topography of goat locations (see below). We divided each year into winter (1 November-15 May), kidding (16 May-15 June), and summer/fall (16 June-31 October). We examined locations and movements of collared goats to identify mineral licks for management planning, both during aerial location flights and subsequently during examination of the GPS location data.

We conducted movement analysis and home range estimation using the Animal Movement extension (Hooge and Eichenlaub 1997*) for ArcView (Environmental Systems Research Institute, Redlands California, USA). We calculated $100 \%$ minimum convex polygon (MCP) home range for all goats monitored for $>1$ year and for calculating seasonal ranges, and removed obvious outliers (i.e., trips to mineral licks) prior to analysis. Seasonal activity centres were calculated using the Spider Diagram option in Animal Movement extension (Hooge and Eichenlaub 1997*) for ArcView.

\section{Habitat Analysis}

Using GIS, we plotted goat locations on digital 1:20 000 scale forest inventory planning maps (forest cover; Resources Inventory Branch 1995), and digital 1:20 000 scale topographic Terrain Resource Information Mapping data (TRIM; Surveys and Resource Mapping Branch 1992). We determined the following characteristics of each goat location: elevation, average location aspect (in $90^{\circ}$ intervals centred on the four cardinal directions), percent slope, the two leading tree species (where available), stand age (projected to 
1997) and crown closure, and whether the area was mapped as currently supporting or could support commercial (potentially merchantable) forest. Aspect, slope and elevation were calculated by creating a triangulated irregular network (TIN) developed from digital elevation models (DEMs), which averaged those parameters over each TIN; TINs were generally 60-100 m on a side. Because goats are reported to be usually within $400 \mathrm{~m}$ of steep, rocky terrain (Smith 1986; Haynes 1992), we created a 50-m grid over the study area, assigned a mean slope to each grid cell, and determined the distance from each GPS collar location to potential escape terrain, which we classified as cells with $>100 \%$ slope. Mapped definitions of escape terrain vary, and range from areas with $>47 \%$ and $\geq 65 \%$ slope for Colorado goats (Varley 1994; Gross et al. 2002), through $>84 \%$ slope in coastal British Columbia (Taylor and Brunt 2003*), to $>100 \%$ slope within the southern Selkirk Mountains of the West Kootenay (Poole and Mowat 1997*). We chose the higher slope to be conservative. We compared distances to escape terrain among seasons using $\log _{10}$ transformed data.

We included VHF locations from both evening and morning telemetry flights in all analyses of VHF-derived data, although we acknowledge that the characteristics of these paired locations were likely correlated. Given the relatively fine-grained environment in which they lived, goats had the opportunity to move among habitat types between flights, even if they did not have time to cross their entire home range. For most analyses, we pooled the VHF locations for all goats throughout the study period, because we had relatively small numbers of locations for a relatively large number of animals (White and Garrott 1990). We compared elevation and slope used among seasons using paired $t$-tests among the means of individual goats, and the distribution of aspects and cover types used among seasons using Chi-squared tests. Using GPS data, we examined the influence of time of day on goat use of elevation and slope, and travel rate for six-hour periods during the day (0030-0630, 00631230, 1230-1830, and 1830-0030 hr) using a repeated measures ANOVA and Ryan's multiple range test (SAS Institute Inc. 1997); travel rate data were $\log _{10}$ trans- formed. Travel rates $(\mathrm{m} / \mathrm{hr})$ were obtained only from GPS locations obtained at six-hour intervals. All analyses were performed using SAS (SAS Institute Inc. 1997) or Statistica (StatSoft Inc. 1997) software. Statistical tests were considered significant at $P<0.05$. Means are presented with associated standard errors (SE), except where noted.

\section{Results}

\section{Goat capture and monitoring}

We captured and collared 21 goats [15 females $(\mathrm{F})$, 6 males (M)] in three sessions (4 F in late July 1997 and $7 \mathrm{~F}$ and $3 \mathrm{M}$ in early September 1997, all with VHF collars; and $3 \mathrm{~F}$ and $4 \mathrm{M}$ in early March 1999, $3 \mathrm{~F}$ and $3 \mathrm{M}$ with GPS collars, $1 \mathrm{M}$ with a VHF collar). Estimated age of goats at capture ranged from 2-9 years for females $(\bar{x}=5.1 \pm 0.49 \mathrm{yr})$ and $5-11$ years for males $(7.6 \pm 0.90 \mathrm{yr})$. One female goat captured in September 1997 died within a week of handling, possibly because of capture myopathy, and was removed from all analyses. Two goats died later in the study, both of unknown natural causes. We obtained 747 VHF collared goat locations (10-57 locations/ goat) between July 1997 and October 1999, and 3639 GPS locations over a 28 -week period from six GPS collars deployed from March to September 1999.

\section{Reliability of the GPS Collar Locations}

Three-dimensional locations were obtained on $80 \%$ of successful locations, and mean location success rate of GPS collars was $76 \%$ (Table 1). Five of the collars functioned much better than the sixth, obtaining locations on $85 \%$ of their attempts. Factors other than forest cover appeared to be responsible for many of missed location attempts because, (1) the VHF-collared goats were found in forest 3.5 times more often in winter than from spring through fall (Table 2), but the proportion of GPS location failures increased only slightly among winter, kidding and summer (means of $13 \%, 13 \%$, and $18 \%$, respectively), and (2) the proportion of $2 \mathrm{D}$ locations remained relatively stable among seasons (means of $18 \%, 19 \%$, and $21 \%$, respectively). The proportion of 2D locations was highest for forest locations (Table 3).

TABLE 1. Success rate of GPS collars programmed to obtain four locations daily, deployed on Mountain Goats in the Robson Valley, British Columbia, March to September 1999.

\begin{tabular}{lccccc}
\hline \hline Goat ID & $\begin{array}{c}\text { Days in } \\
\text { field }\end{array}$ & $\begin{array}{c}\text { Number of } \\
\text { locations }\end{array}$ & $\begin{array}{c}\text { \% of expected } \\
\text { locations }\end{array}$ & $\begin{array}{c}\text { 2D locations } \\
\text { (\% of total no. })\end{array}$ & $\begin{array}{c}\text { 3D locations } \\
(\% \text { of total no. })\end{array}$ \\
\hline 9917 & 195 & 240 & 31 & 23 & 77 \\
9918 & 195 & 629 & 81 & 28 & 72 \\
9919 & 204 & 703 & 88 & 19 & 81 \\
9920 & 204 & 719 & 86 & 20 & 94 \\
9921 & 204 & 714 & 88 & 27 & 73 \\
9923 & 194 & 634 & 76 & 20 & 80 \\
Weighted mean & 199 & 607 & & & \\
\hline \hline
\end{tabular}


TABLE 2. Distribution (\%) of forest cover descriptors in polygons containing VHF locations for 21 Mountain Goats, July 1997 to October 1999, and GPS locations from six goats, March to September 1999, Robson Valley, British Columbia. Winter covers 1 November to 15 May.

\begin{tabular}{llcccrc}
\hline \hline \multirow{2}{*}{ Collar type } & \multicolumn{1}{c}{ Season } & $n$ & Alpine & $\begin{array}{c}\text { Alpine } \\
\text { forest }\end{array}$ & $\begin{array}{c}\text { Commercial } \\
\text { forest }\end{array}$ & Other $^{a}$ \\
\hline \multirow{2}{*}{ VHF } & Winter & 287 & 59 & 9 & 26 & 7 \\
& Spring to fall & 460 & 84 & 4 & 7 & 5 \\
\multirow{2}{*}{ GPS } & Late winter & 1324 & 75 & 6 & 9 & 10 \\
& Spring to late summer & 2315 & 86 & 2 & 7 & 6 \\
\hline \hline
\end{tabular}

${ }^{a}$ Other included clearings, clay banks, rock, non-productive brush and burns, and non sufficiently restocked areas.

TABLE 3. Percent of 2D and 3D locations from GPS radio collars within broad vegetation cover types (defined by biogeoclimatic zone and forest cover mapping) from Mountain Goats in the Robson Valley, British Columbia, March to September 1999.

\begin{tabular}{|c|c|c|c|c|c|}
\hline \multirow[t]{2}{*}{ Location type } & \multicolumn{2}{|c|}{ Biogeoclimatic zone ${ }^{a}$} & \multicolumn{3}{|c|}{ Forest $\operatorname{cover}^{b}$} \\
\hline & Alpine tundra & $\mathrm{ESSF}^{c}$ & Alpine & Alpine forest & Forest \\
\hline$n$ & 2984 & 655 & 3005 & 367 & 267 \\
\hline $2 \mathrm{D}$ & 18 & $28^{d}$ & 18 & 27 & 36 \\
\hline $3 \mathrm{D}$ & 82 & 72 & 83 & 73 & 64 \\
\hline
\end{tabular}

${ }^{a} \chi_{1}^{2}=1830, P<0.0001$.

${ }^{b} \chi_{2}^{2}=1680, P<0.0001$.

${ }^{c}$ ESSF = Engelmann Spruce - Subalpine Fir biogeoclimatic zone.

${ }^{d}$ Includes one location in ICH (Interior Cedar Hemlock).

Although we can never know where the goats were when the collars failed to obtain a location, we used data from the five GPS collars that had no obvious technical malfunctions (i.e., excluding goat 9917) to assess the magnitude of any bias against forest locations. If location success was reduced when goats were in the forest and if goats tended to remain in the forest for $>1$ location attempt, then missed location attempts should be more common following a forest location than following an alpine location. For all five collars, forest locations were far more likely than non-forest locations to be followed by a forest location (means of $53 \%$ versus $7 \%$, respectively) but missed locations were only slightly more common following forest locations (mean of $20 \%$ versus $16 \%$, respectively). We inferred from these data that the magnitude of the bias against obtaining a forest location was about $23 \%$ (the ratio of the proportion of forested zones in the location subsequent to a missed location compared to a successful location; 20.1\%/16.3\%).

\section{Population Scale Movements}

As expected, all goats used steep terrain and were found at lower elevations during winter. The goats monitored for $>1$ year followed one of two seasonal movement patterns. Eight of 11 goats occupied relatively small $\left(12-17 \mathrm{~km}^{2}\right.$ ) home ranges with primarily seasonal shifts in elevation, while three exhibited longer horizontal shifts, moving 8-13 km between seasonal activity centres. Only two collared goats could be considered as belonging to the same herd; both these animals made primarily elevational shifts in range use. Movement to wintering areas usually occurred between early October and late November, with an initial drop to lower elevations followed by a slight increase in elevation during December (Figure 2). Only two male goats were monitored during the first winter, and both wintered at low elevations (Figure 2). Both VHF and GPS data suggested that initial movements to lower elevations coincided with the first fall snowstorm. The two adult female goats wearing GPS collars in late September descended roughly $500 \mathrm{~m}$ in elevation during and just after the winter's first snowstorm on 24-25 September, while the only male still with a GPS collar at that time descended about $100 \mathrm{~m}$. Movement to higher elevation summer range generally took place during June and July. Most goats (8 out of 12) wintered in the same area both winters, but three females and one male shifted wintering areas between years. Mean home range size $(100 \% \mathrm{MCP})$ of female goats was $27.0 \mathrm{~km}^{2}\left( \pm 8.50 ; n=10\right.$, range $\left.=6-98 \mathrm{~km}^{2}\right)$. The two males had home ranges of 13.7 and $65.3 \mathrm{~km}^{2}$. Goats tended to move very little over winter. Mean movement rates of the five goats carrying functioning GPS collars ranged from $24-36 \mathrm{~m} / \mathrm{h}$ in winter and from $60-115 \mathrm{~m} / \mathrm{h}$ during summer, with winter range size often very small. One female used areas of about 15 and 35 ha located $1.5 \mathrm{~km}$ apart in successive winters, and one male wintered both years in the same 72 ha area. 


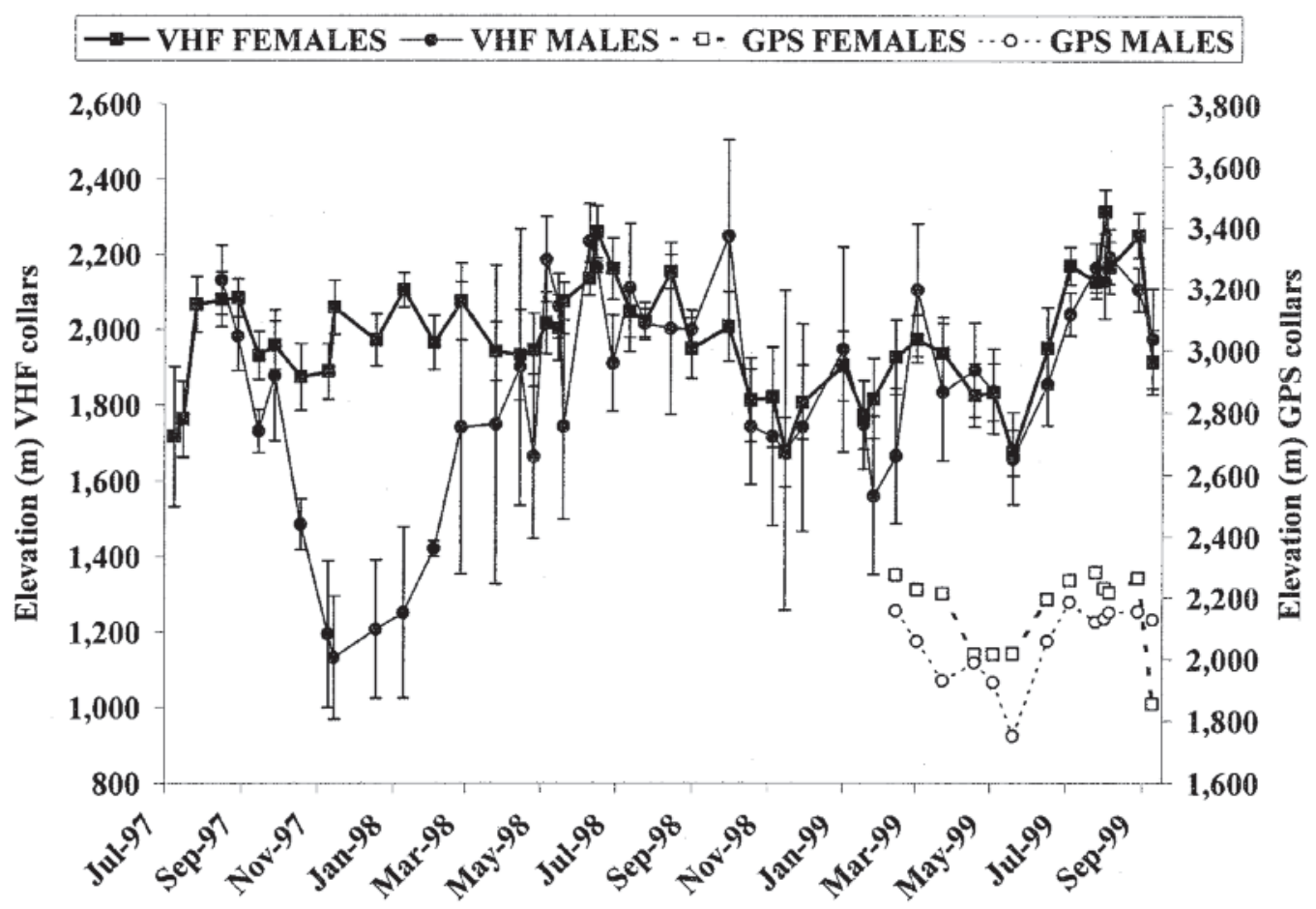

FIGURE 2. Mean elevation $(\mathrm{m} \pm \mathrm{SE}$ ) of female and male VHF-collared Mountain Goats (solid lines and left axis) plotted by telemetry flight, September 1997 - October 1999, and male and female GPS-collared Mountain Goats (dashed lines and right axis), March - September 1999, Robson Valley, British Columbia. The right axis was offset to show the GPS collars separately. VHF sample sizes were 6-13 for females and 2-6 for males (only two males were monitored the first winter); GPS sample sizes were three male and three female goats.

\section{Habitat Use}

Goats used lower elevations during winter (1 November -15 May; $\bar{x}=1730 \pm 59 \mathrm{~m} ; n=12$ ) compared with the rest of the year $\left(\bar{x}=1920 \pm 43 \mathrm{~m} ; n=12 ; t_{11}=\right.$ $3.9, P=0.0024$; Figure 2). Ninety percent of winter goat locations were between 1330 and $2320 \mathrm{~m}$ in elevation $(n=287)$. Mean annual slope use among goats monitored $>1$ year averaged $79 \%$ ( $\pm 2.1 \%)$. Goats occupied slopes of similar steepness in winter as they did during the rest of the year $\left(t_{11}=1.0, P=0.35\right)$. GPS-collared goats were closer to escape terrain during late winter than during the snow-free periods $(n=$ $5 ; t=2.03, P=0.04$ ) with use declining with increasing distance from escape terrain, especially beyond $500 \mathrm{~m}$ (Figure 3). Seventy percent of locations during winter and $62 \%$ during summer were $<500 \mathrm{~m}$ from escape terrain.

Southern aspects were used more often (44\% of locations) throughout the year by VHF-collared goats than were other aspects, and east and west aspects were used less often than would be expected from a random distribution $\left(\chi_{3}^{2}=410, P<0.0001\right)$. Goats were located $15 \%$ more often on south aspects during winter than from spring to fall $\left(\chi_{3}^{2}=45.6, P<0.0001\right)$.
Over the year, $70 \%$ of VHF locations of goats were found in the AT biogeoclimatic zone, $29 \%$ were in the ESSFmm1 (moist, mild) subzone/variant; and 1.2\% (9 locations) were found in the ICH zone. Overall, $14 \%$ of VHF goat locations were in forest cover polygons mapped as commercial forest and most locations were in the alpine (Table 3). Seven percent of GPS locations were in commercial forest. Use of alpine areas increased between winter and snow-free seasons for both VHF-collared goats monitored over the entire year, and GPS-collared goats monitored from March to September; use of commercial forests by VHFcollared goats increased to $26 \%$ during winter (VHF: $\chi_{3}^{2}=66.6, P<0.0001$; GPS: $\chi_{3}^{2}=89.7, P<0.0001$; Table 3). As summer progressed all GPS-collared animals were found almost exclusively in the alpine, including $98 \%$ of all locations after 12 July.

Subalpine Fir, spruce, and Lodgepole Pine were the leading tree species $(64-71 \%$ of the total gross volume of each stand) in commercial forest stands where collared goats were located, and spruce, Subalpine Fir, Lodgepole Pine and Whitebark Pine were most prevalent as the second species (23-25\% of volume; Table 4). Trees in alpine forest polygons were prima- 


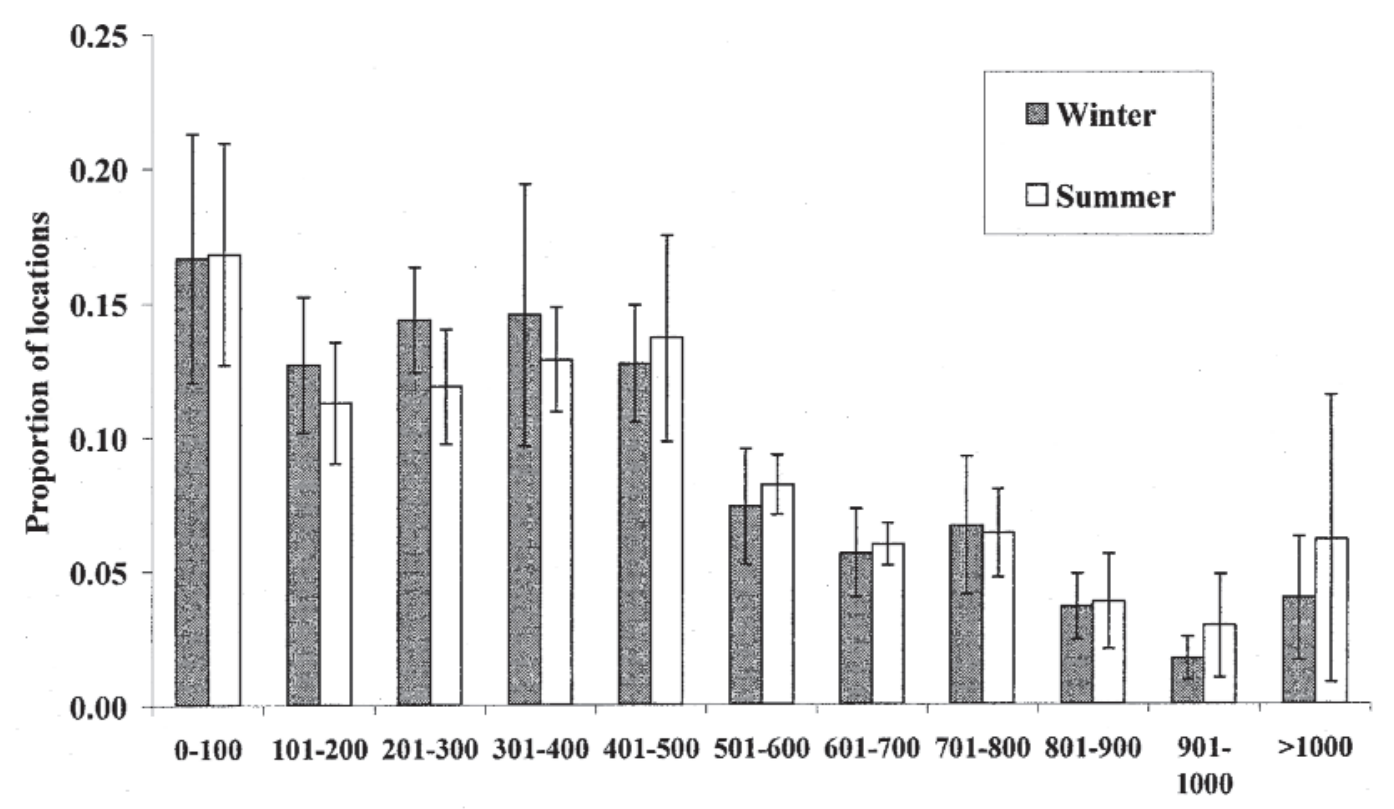

Distance to $>100 \%$ slope $(\mathrm{m})$

FIGURE 3. Proportion of GPS collared goat locations $( \pm$ SE) in relation to distance from escape terrain (areas of $>100 \%$ slope) for six Mountain Goats, Robson Valley, March - September 1999. Winter covers the period from early March to 31 May; summer from 1 June to late September.

rily Subalpine Fir or a mix of Subalpine Fir and spruce. Ninety-eight per cent of commercial forest stands $(n=$ $372)$ were mature ( $81-140$ years; $25 \%)$ or old $(>140$ years; $73 \%$ ), while only $2 \%$ were immature (21-80 years). Subalpine Fir and spruce dominated old stands. All but six alpine forest stands were mature or old in age $(n=155)$. Crown closure of stands used during winter ranged from 5 to $65 \%$, with $79 \%$ of goat use in stands with between 26 and $45 \%$ crown closure.

Using GPS collar data, the period of the day appeared to affect elevation used and movement rates but not slope or aspect. The goats were found on average 50 to $70 \mathrm{~m}$ lower in elevation from evening to dawn (1830-0630 hr) compared with the rest of the day and movement rates were lower during the period from 0030 to $0630 \mathrm{~h}$ (Table 5). There was no difference among periods of the day in aspect selected $\left(\chi_{9}^{2}=14.1\right.$, $P=0.12)$ or in the use of broad forest cover type $\left(\chi_{9}^{2}=\right.$ $7.9, P=0.54)$.

\section{Mineral Licks}

Local residents told us of the location of 16 goat mineral licks that were primarily from low and midelevations in the northern half of the study area (G. Calef and D. Heard, unpublished data). Three of the VHF-collared goats spent time at or near three of these mid-elevation licks during the study. We located three new mineral licks or focal areas (areas which we assumed contained licks because goats seemed to con- centrate their activity there in the same way they did at known mineral licks, but where we could not find a specific lick site), all at upper elevations (2000-2300 m) and all in the alpine zone in the southern portion of the study area. Six collared goats visited these licks. One of the areas was within a goat's home range, and two were located 6-14 km outside of normal home ranges (Figure 4). GPS collar locations suggested visits to the sites lasted from $<24 \mathrm{~h}$ to four days. Visits to all licks or focal areas occurred from March through November, with most use of high-elevation sites between June and September.

\section{Discussion}

Movements and Habitat Use

As expected, at the population scale goats in the Robson Valley generally used high, steep terrain. The goats spent up to $26 \%$ of the winter in potentially merchantable timber stands when they were not using low-snow areas near or above treeline. Those seasonal movements and habitat use were similar to goats occupying other dry interior regions (Smith 1977; Adams and Bailey 1983). Goats living in coastal and wet interior climates, where winter snow fall is much greater, typically spend more time in forests (e.g., over $85 \%$ of winter goat locations in coastal Alaska occurred in forests [Smith 1986]) presumably because goats prefer the lower snow depths found under trees 
TABLE 4. Distribution (\%) of the first and second leading commercial tree species (by gross volume) in forest cover polygons containing VHF locations for Mountain Goats, July 1997 - March 1999, and GPS locations from six goats, March to September 1999, Robson Valley, British Columbia.

\begin{tabular}{|c|c|c|c|c|c|c|c|c|}
\hline \multicolumn{2}{|c|}{ Collar type } & \multirow{2}{*}{$\frac{n}{105}$} & \multirow{2}{*}{$\begin{array}{c}\begin{array}{c}\text { Subalpine } \\
\text { Fir }\end{array} \\
39\end{array}$} & \multirow{2}{*}{$\begin{array}{c}\text { Spruce } \\
25\end{array}$} & \multirow{2}{*}{$\begin{array}{c}\begin{array}{c}\text { Lodgepole } \\
\text { Pine }\end{array} \\
18\end{array}$} & \multirow{2}{*}{$\begin{array}{c}\begin{array}{c}\text { Douglas- } \\
\text { Fir }\end{array} \\
7\end{array}$} & \multirow{2}{*}{$\begin{array}{c}\text { Whitebark } \\
\text { Pine }\end{array}$} & \multirow{2}{*}{$\frac{\text { Other }^{a}}{7}$} \\
\hline VHF & Leading & & & & & & & \\
\hline VHF & Second & 104 & 33 & 30 & 16 & 4 & 13 & 4 \\
\hline GPS & Leading & 417 & 77 & 13 & 1 & 0 & 9 & 0 \\
\hline GPS & Second & 406 & 18 & 32 & 18 & 0 & 32 & 0 \\
\hline
\end{tabular}

${ }^{a}$ Other includes aspen (Populus tremuloides), Paper Birch (Betula papyrifera), Western Redcedar, and Western Hemlock.

TABLE 5. Elevation, slope, and travel rate for six GPS-collared Mountain Goats by six-hour periods, Robson Valley, March-September 1999.

\begin{tabular}{|c|c|c|c|c|c|c|c|}
\hline \multirow[b]{2}{*}{ Period (hr) } & \multirow[b]{2}{*}{$n$} & \multicolumn{2}{|c|}{ Elevation $(\mathrm{m})^{a}$} & \multicolumn{2}{|c|}{ Slope $(\%)^{b}$} & \multicolumn{2}{|c|}{ Travel rate $(\mathrm{m} / \mathrm{hr})^{c}$} \\
\hline & & $\overline{\mathrm{x}}$ & $\overline{\mathrm{SE}}$ & $\overline{\mathrm{x}}$ & $\overline{\mathrm{SE}}$ & $\overline{\mathrm{x}}$ & $\overline{\mathrm{SE}}$ \\
\hline $0030-0630$ & 898 & $2060 B^{d}$ & 8 & 78 & 0.9 & $35 \mathrm{~B}$ & 1.7 \\
\hline $0630-1230$ & 918 & $2130 \mathrm{~A}$ & 8 & 78 & 1.0 & $68 \mathrm{~A}$ & 3.9 \\
\hline $1230-1830$ & 891 & $2130 \mathrm{~A}$ & 8 & 77 & 1.0 & $64 \mathrm{~A}$ & 3.0 \\
\hline $1830-0030$ & 926 & 2080B & 8 & 77 & 1.0 & $67 \mathrm{~A}$ & 3.3 \\
\hline
\end{tabular}

${ }^{a} F_{3,5}=16.5, P<0.0001$

${ }^{b} F_{3,5}=0.7, P=0.55$

${ }^{c} F_{3,5}=35.4, P<0.0001\left(\log _{10}\right.$ transformed data)

${ }^{\mathrm{d}}$ Means within a column with the same letter did not differ.

(Smith 1977; Hebert and Turnbull 1977; McCrory et al. 1977; Adams and Bailey 1983; Fox and Smith 1988; Gilbert and Raedeke 1992). Robson Valley goats wintered in forests primarily composed of open mature or old-aged Subalpine Fir and spruce stands at the upper reaches of continuously forested slopes. While mapped as potential commercial forest in the forest cover database, most of these stands were located on steep terrain and were interspersed with or adjacent to small to medium-sized $(5-20 \mathrm{~m})$ cliffs that would not be mapped in the forest cover database (K. Poole and D. Heard, personal observations). While those stands could have forestry development potential, over the short to medium term their economic value is low compared to stands at lower elevation and on less steep and broken slopes.

We observed changes in elevation that were probably related to snow conditions and food availability. Goats moved lower with the first heavy winter snowfall and with the onset of the spring vegetation greenup. Goats moved up through late spring and summer, likely, as suggested by Varley (1994), coinciding with greening up of vegetation and snow melt at progressively higher elevations. Areas used over winter before the firming of the snow crust in late winter were often very small.

Seasonal movement patterns varied from short shifts up and down a mountain face, to movements among distant areas. Those differences in movement patterns account for the large differences in home range size among individuals. Overall both the mean and the variation among home range size of female goats in the Robson Valley was similar to published $100 \%$ MCP home range sizes of female goats' range from other areas (means among studies of $8.9-25.0 \mathrm{~km}^{2}$ for females; Rideout 1978; Singer and Doherty 1985; Côté and Festa-Bianchet 2003).

\section{Focal Areas and Mineral Licks}

Prior to this study, most of the known goat mineral licks in the Robson Valley were typical seeps or cut banks (Hebert and Cowan 1971), and in forested valley bottoms where people would be most likely to find them. During this study we were able to identify three new high elevation mineral licks or focal areas. High elevation licks have also been reported near edges of glaciers, glacier moraines, caves, limestone outcrops, and shale cliffs elsewhere in British Columbia (McCrory 1979*). We could have missed movements of VHF collared goats to mineral licks, but because of the high location success of the GPS collars and the relatively low bias against forest locations, we believe it unlikely that we failed to detect use of other licks outside of their normal home ranges. The comparatively low incidence of long-distant movements by GPS-collared goats suggests that sources of minerals may be more widespread in the Robson Valley than elsewhere. While prevalent in most goat populations, 


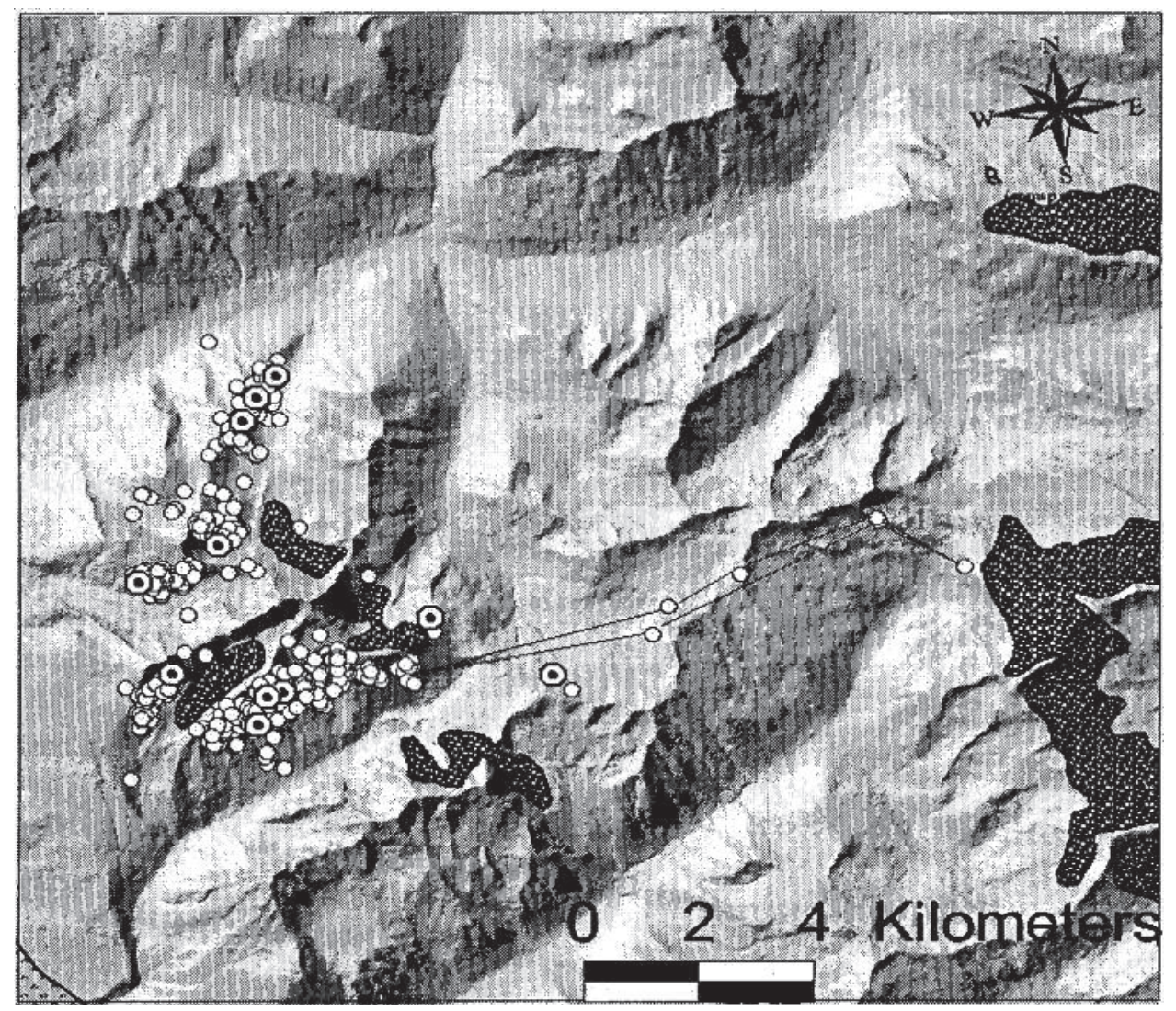

FIGURE 4. Locations and movements of adult female Mountain Goat 9919 in the Robson Valley, British Columbia, 9 March to 29 September 1999, based on locations determined by the GPS receiver in the radio-collar ( $n=703$, open circles) and by tracking the VHF signal from the radio-collar ( $n=11$, dots within circles). Line joins the eight consecutive GPS location points from 17 and 18 August 1999 where the Mountain goat was found during a movement to a focal area outside of her normal home range. Dark stippled areas represent glaciers.

use of mineral licks by goat populations is not universal (Varley 1994) and there is a great deal of individual variation among goats in the number of lick visits, timing and duration of visits, and distance traveled to licks (Hebert and Cowan 1971; Singer and Doherty 1985; Hopkins et al. 1992; Klaus and Schmid 1998; Lemke 1999*). Our observations were consistent with the generalization that peak use of licks varies with elevation, with higher elevation licks being used later in the season (Hebert and Cowan 1971).

\section{GPS Technology}

GPS collars can provide numerous precise locations, but because location success is always $<100 \%$ the recorded positions are undoubtedly biased. Location success is related to differences in overstory vegetation (Rempel et al. 1995; Moen et al. 1996; Dussault et al. 1999; D'Eon et al. 2002), topography (D'Eon et al. 2002), and animal behaviour (Edenius 1997; Bowman et al. 2000; Moen et al. 2001). The GPS locations likely underestimated the use of forest stands with higher crown closures and stem densities. Quantifying this bias is difficult, but we suggest that forest use may be underestimated by about $23 \%$ because VHF collar data suggested higher use of commercial forests by goats during winter than the GPS collar data. However, forest use during late winter (when the GPS collars were deployed) and the firming of snow conditions may be less than found during other periods of the winter. This study was not a good test of the impact of canopy closure on GPS location success, because even when located in an area mapped as "forest", goats may have been on small cliffs with little or no adjacent tall vegetation, and not in stands with continuous crown closure. Our data suggests that factors other than vegetation cover density were also responsible for 
many of the missed location attempts because collar acquisition success did not differ between summer, when it was highly unlikely that goats were ever in forests, and other seasons. It may be possible to define correction factors better using field trials, or increased spatial modeling and examination using GIS (e.g., D'Eon et al. 2002).

Most studies of bias in GPS location success have been conducted in relatively flat terrain in central and eastern North America, and the results from studies in mountainous terrain provide conflicting results as to the impact of topography (Dussault et al. 1999; D'Eon et al. 2002). The $76 \%$ location success rate in this study was at the upper end of the range reported elsewhere (Johnson et al. 2002). GPS collars may be particularly appropriate for studies on goats and other animals living in rugged, non-forested or lightly forested terrain, or when detection of short-term movements outside of an animal's normal home range is required.

The GPS collar data suggested that goats conducted movements to lower elevations during the evening to dawn period. This finding suggests that VHF-based locations on goats and possibly other species may be biased where safety and logistics dictate that animal locations be taken during daylight hours and in good weather, e.g., when telemetry locations are required from aircraft.

\section{Management Implications}

The absence of detected goat movements to lowelevation sites and limited movements to areas outside of their normal home ranges suggests that the minerals sought by goats in the Robson Valley during spring and summer may be widely available. This would further suggest that goats in the Robson Valley may face less risk to disturbance from forestry development at mineral licks, since few appear to use low elevation licks.

Robson Valley goats also appeared to be at relatively low risk from logging on their winter range. While we demonstrated that goats in the Robson Valley use forests, primarily during winter, most of these stands were on steep slopes in association with scattered, nonforested cliffs at the upper edge of continuous forested habitats. The timber in these areas appeared to be of low commercial value over at least the short to medium term. Forest development planning can incorporate low elevation forest and mineral lick use by goats by avoiding development adjacent to cliffs located in forested habitats. The reported distance from escape terrain within which goats are most often found varies from 260-500 m (Fox 1983; Smith 1994; Poole and Mowat 1997*; Gross et al. 2002). In the Robson Valley, a forested buffer of $500 \mathrm{~m}$ around cliffs should be left to reduce the possibility of adverse effects on goats; these buffers should be especially enforced around cliffs on southern aspects and at elevations down to about $1300 \mathrm{~m}$.

\section{Acknowledgments}

Funding was provided by Forest Renewal British Columbia, Resources Inventory Program, and was administered by British Columbia Ministry of Environment, Lands and Parks (MELP), Prince George, British Columbia. G. Watts, J. Hooge, C. Leake, H. Schwantje, and M. Badry provided field and study assistance, G. Calef summarized mineral lick use by goats in the region, and W. Poole provided rock identification. C. Ritchie, MELP, Prince George, provided input on forestry development in the region. $\mathrm{C}$. Wilson, B. Scott, B. Minor, G. Altoft, and G. Watts captured the goats, and B. McPherson, D. Brady, and C. Blunt provided additional helicopter support. D. Mair provided excellent and enthusiastic piloting for telemetry flights. We thank C. Kochanny and N. Christensen at ATS, Isanti, Minnesota, for technical support during the project. D. Pritchard conducted the GIS analyses. G. Mowat, M. Festa-Bianchet, and two anonymous reviewers commented on earlier drafts of the manuscript. Mention of brand names or commercial products is solely for the purpose of description and does not imply endorsement by the authors or affiliated agencies.

\section{Documents Cited (marked * after year in text)}

British Columbia Ministry of Environment, Lands and Parks. 1995. British Columbia standards, specifications and guidelines for resource surveys using global positioning system (GPS) technology. Ministry of Environment, Lands and Parks, Surveys and Resource Mapping Branch, Victoria, British Columbia, Canada.

Hooge, P. N., and B. Eichenlaub. 1997. Animal movement extension to ArcView. Version 1.1. Alaska Biological Science Center, U.S. Geological Survey, Anchorage, Alaska, USA.

Lemke, S. L. 1999. Cayoosh Range mountain goat study results and recommendations. Unpublished report for BC Ministry of Environment, Lands and Parks, Kamloops, British Columbia, Canada.

Lotek Engineering. 1998. N3WIN Differential Post-processing Software User's Manual (Release 2.40: January 1998). Lotek Engineering, Newmarket, Ontario, Canada.

McCrory, W. P. 1979. An inventory of the mountain goats of Glacier and Mount Revelstoke National Parks, British Columbia. Unpublished report. Parks Canada, Western Region, Glacier National Park, Revelstoke, British Columbia, Canada.

Poole, K. G., and G. Mowat. 1997. Mountain goat winter habitat use in the West Kootenay Region of British Columbia. Unpublished report for B.C. Ministry of Environment, Lands and Parks, Nelson, British Columbia.

Taylor, S. D., and K. Brunt. 2003. Winter habitat use by mountain goats in the Kingcome River drainage of coastal British Columbia. Unpublished report for B.C. Ministry of Water, Land and Air Protection, Naniamo.

Trimble Navigation Ltd. 1994. Mapping systems: general reference. Trimble Navigation Ltd., Sunnyvale, California, USA. 


\section{Literature Cited}

Adams, L. A., and J. A. Bailey. 1983. Winter forages of mountain goats in central Colorado. Journal of Wildlife Management 47: 1237-1243.

Bowman, J. L., C. O. Kochanny, S. Demarais, and B. D. Leopold. 2000. Evaluation of a GPS collar for whitetailed deer. Wildlife Society Bulletin 28: 141-145.

Côté, S. D., and M. Festa-Bianchet. 2003. Mountain goat. Pages 1061-1075 in Wild mammals of North America: biology, management, and conservation. Edited by G. A. Feldhamer, B. Thompson, and J. Chapman. The John Hopkins University Press, Baltimore, Maryland.

Demarchi, M. W., S. R. Johnson, and G. F. Searing. 2000. Distribution and abundance of mountain goats, Oreamnos americanus, in westcentral British Columbia. Canadian Field-Naturalist 114: 301-306

D'Eon, R. G., R. Serrouya, G. Smith, and C. O. Kochanny. 2002. GPS radiotelemetry error and bias in mountainous terrain. Wildlife Society Bulletin 30: 430-439.

Dussault, C., R. Courtois, J.-P. Ouellet, and J. Huot. 1999. Evaluation of GPS telemetry collar performance for habitat studies in the boreal forest. Wildlife Society Bulletin 27: 965-972.

Edenius, L. 1997. Field test of a GPS location system for moose Alces alces under Scandinavian boreal conditions. Wildlife Biology 3: 39-43.

Fox, J. L. 1983. Constraints on winter habitat selection by the mountain goat, Oreamnos americanus, in Alaska. Ph.D. dissertation, University of Washington, Seattle.

Fox, J. L., and C.A. Smith. 1988. Winter mountain goat diets in southeast Alaska. Journal of Wildlife Management 52: $362-365$.

Gilbert, B. A., and K. J. Raedeke. 1992. Winter habitat selection of mountain goats in the North Tolt and Mine Creek drainages of the North Central Cascades. Biennial Symposium of the Northern Wild Sheep and Goat Council 8: 305-324.

Gross, J. E., M. C. Kneeland, D. F. Reed, and R. M. Reich. 2002. GIS-based habitat models for mountain goats. Journal of Mammalogy 83: 218-228.

Haynes, L. A. 1992. Mountain goat habitat of Wyoming's Beartooth Plateau: implications for management. Biennial Symposium of the Northern Wild Sheep and Goat Council 8: 325-339.

Hebert, D., and I. M. Cowan. 1971. Natural salt licks as a part of the ecology of the mountain goat. Canadian Journal of Zoology 49: 605-610.

Hebert, D., and W. G. Turnbull. 1977. A description of southern interior and coastal mountain goat ecotypes in British Columbia. Pages 126-146 in Proceedings of the First International Mountain Goat Symposium, Kalispell, Montana. Edited by W. M. Samuel and W. G. Macgregor. British Columbia Fish and Wildlife Branch, Victoria, British Columbia, Canada.

Hopkins, A., J. P. Fitzgerald, A. Chappell, and G. Byrne. 1992. Population dynamics and behavior of mountain goats using Elliot Ridge, Gore Range, Colorado. Biennial Symposium of the Northern Wild Sheep and Goat Council 8: 340-356.

Johnson, C. J. 2000. A multi-scale behavioural approach to understanding the movements of woodland caribou. Ph.D. thesis, The University of Northern British Columbia, Prince George, British Columbia, Canada.

Johnson, C. J., D. C. Heard, and K. L. Parker. 2002. Expectations and realities of GPS animal location collars: results of three years in the field. Wildlife Biology 8: 153-159.

Klaus, G., and B. Schmid. 1998. Geophagy at natural licks and mammal ecology: a review. Mammalia 62: 481-497.

McCrory, W. P., D. A. Blood, D. Portman, and D. Harwood. 1977. Mountain goat surveys in Yoho National Park, British Columbia. Pages 69-73 in Proceedings of the First International Mountain Goat Symposium, Kalispell, Montana. Edited by W. M. Samuel and W. G. Macgregor. British Columbia Fish and Wildlife Branch, Victoria, British Columbia, Canada.

MacKinnon, A., J. Pojar, and R. Coupé. Editors. 1992. Plants of northern British Columbia. Lone Pine Publishing, Vancouver, British Columbia, Canada.

Mech, L. D. 1983. Handbook of animal radio-tracking. University of Minnesota Press, Minneapolis, Minnesota, USA.

Mech, L. D., and E. M. Gese. 1992. Field testing the Wildlink capture collar on wolves. Wildlife Society Bulletin 20: $249-256$.

Meidinger, D., and J. Pojar. 1991. Ecosystems of British Columbia. Special Report Series 6, British Columbia Ministry of Forests, Research Branch, Victoria, British Columbia, Canada.

Moen, R., J. Pastor, Y. Cohen, and C. C. Schwartz. 1996. Effects of moose movement and habitat use on GPS collar performance. Journal of Wildlife Management 60: 659668.

Moen, R., J. Pastor, and Y. Cohen. 2001. Effects of animal activity on GPS telemetry location attempts. Alces 37: 207-216.

Poole, K. G., and D. C. Heard. 1998. Habitat use and movements of mountain goats as determined by prototype GPS collars, Robson Valley, British Columbia. Biennial Symposium of the Northern Wild Sheep and Goat Council 11: 22-35.

Poole, K. G., D. C. Heard, and G. S. Watts. 2000. Mountain goat inventory in the Robson Valley, British Columbia. Biennial Symposium of the Northern Wild Sheep and Goat Council 12:114-124.

Rempel, R. S., A. R. Rodgers, and K. F. Abraham. 1995. Performance of a GPS animal location system under boreal forest canopy. Journal of Wildlife Management 59: 543-551.

Resources Inventory Branch. 1995. Relational data dictionary (RDD) 2.0. British Columbia Ministry of Forests, Victoria.

Rideout, C. B. 1978. Mountain goat. Pages 149-159 in Big game of North America - ecology and management. Edited by J. L. Schmidt and D. L. Gilbert. Wildlife Management Institute, Stackpole Books, Harrisburg, Pennsylvania, USA.

SAS Institute. 1997. SAS/STAT software: changes and enhancements through release 6.12. SAS Institute, Cary, North Carolina, USA.

Shackleton, D. 1999. Hoofed mammals of British Columbia. The Mammals of British Columbia, Volume 3, Royal British Columbia Museum. UBC Press, Vancouver.

Singer, F. J., and J. L. Doherty. 1985. Movements and habitat use in an unhunted population of mountain goats, Oreamnos americanus. Canadian Field-Naturalist 99: 205-217.

Smith, B. L. 1977. Influence of snow condition on winter distribution, habitat use, and group size of mountain goats. Pages 174-189 in Proceedings of the First International Mountain Goat Symposium, Kalispell, Montana. Edited by 
W. M. Samuel and W. G. Macgregor. British Columbia Fish and Wildlife Branch, Victoria, British Columbia, Canada.

Smith, B. L. 1988. Criteria for determining age and sex of American mountain goats in the field. Journal of Mammalogy 69: 395-402.

Smith, C. A. 1986. Habitat use by mountain goats in southeastern Alaska. Final Report, Project W-22-1, -2, and -3. Alaska Department of Fish and Game, Juneau, Alaska, USA.

Smith, C. A. 1994. Evaluation of a multivariate model of mountain goat winter habitat selection. Biennial Symposium of the Northern Wild Sheep and Goat Council 9: $159-165$.

Statsoft Inc. 1997. STATISTICA for Windows. Release 5.1. StatSoft, Tulsa, Oklahoma, USA

Stevens, V., and D. B. Houston. 1989. Reliability of age determination of mountain goats. Wildlife Society Bulletin 17: $72-74$.
Surveys and Resource Mapping Branch. 1992. Digital baseline mapping at 1:20,000. British Columbia specifications and guidelines for geomatics. Content Series Volume 3. Release 2.0. British Columbia Ministry of Environment, Lands and Parks, Victoria, British Columbia, Canada.

Varley, N. C. 1994. Summer-fall habitat use and fall diets of mountain goats and bighorn sheep in the Absaroka Range, Montana. Biennial Symposium of the Northern Wild Sheep and Goat Council 9: 131-138.

White, G. C., and R. A. Garrott. 1990. Analysis of wildlife radio-tracking data. Academic Press, Toronto, Ontario, Canada.

Received 17 December 2001

Accepted 20 April 2004 